Article

\title{
Sustainable Recycling of Electric Arc Furnace Steel Slag as Aggregate in Concrete: Effects on the Environmental and Technical Performance
}

\author{
Alessandra Diotti ${ }^{1, *}$, Luca Cominoli ${ }^{1}$, Adela Perèz Galvin ${ }^{2}$, Sabrina Sorlini ${ }^{1}$ and Giovanni Plizzari ${ }^{1}$ \\ 1 Department of Civil Engineering, Architecture, Land, Environment and Mathematics, University of Brescia, \\ Via Branze 43, 25123 Brescia, Italy; luca.cominoli@unibs.it (L.C.); sabrina.sorlini@unibs.it (S.S.); \\ giovanni.plizzari@unibs.it (G.P.) \\ 2 Construction Engineering, UCO-Ed, Leonardo Da Vinci, Campus of Rabanales, University of Córdoba, \\ 14071 Cordoba, Spain; apgalvin@uco.es \\ * Correspondence: a.diotti@unibs.it
}

check for updates

Citation: Diotti, A.; Cominoli, L.; Galvin, A.P.; Sorlini, S.; Plizzari, G. Sustainable Recycling of Electric Arc Furnace Steel Slag as Aggregate in

Concrete: Effects on the Environmental and Technical Performance. Sustainability 2021, 13, 521. https://doi.org/10.3390/ su13020521

Received: 27 November 2020

Accepted: 3 January 2021

Published: 7 January 2021

Publisher's Note: MDPI stays neutral with regard to jurisdictional clai$\mathrm{ms}$ in published maps and institutional affiliations.

Copyright: () 2021 by the authors. Licensee MDPI, Basel, Switzerland. This article is an open access article distributed under the terms and conditions of the Creative Commons Attribution (CC BY) license (https:// creativecommons.org/licenses/by/ $4.0 /)$.

\begin{abstract}
The aim of this research work was the evaluation of the feasibility to utilize industrial by-products, such as electric arc furnace steel slags, for sustainable concrete production. The paper evaluated the environmental and mechanical properties of steel slags and concrete, respectively. Specifically, the release of contaminants from steel slags was investigated by leaching test and the properties of fresh and hardened concrete were evaluated for a concrete mixture designed with a partial substitution $(30 \%)$ of natural coarse aggregates with electric arc furnace steel slags. The results show that the concentrations of pollutants were lower than the legal limits imposed by the Ministerial Decree 186/2006 and the addition of steel slag can enhance the mechanical performance of concrete. The compressive strength of cubic specimens was also measured after different cycles of alternate wetting-drying. The steel slag incorporation results in a stiffness comparable to that of a traditional concrete. Overall, the mechanical and leaching characterization has shown that the reuse of electric arc furnace steel slags for sustainable concrete production is feasible and reliable.
\end{abstract}

Keywords: recycling; EAF steel slag; leaching behavior; concrete; mechanical properties

\section{Introduction}

Sustainability can build value in construction and design of green buildings. A sustainable approach to construction brings environmental, social, and economic benefits to a construction project. From this perspective, several resources from industries and construction waste are used to manufacture sustainable green concretes. Steel slags, fly ash, granulated blast furnace slag, silica fumes, recycled aggregates from construction and demolition waste, and many other are nonbiodegradable materials used in concrete by replacing one of its components. Incorporating recycled materials in concrete prevents large land areas from being landfilled, reduces the extraction of virgin raw materials and the environmental pollution, and contributes to achieving a circular economy [1].

The steelmaking process contributes to a considerable production of industrial byproducts, including steel slags. The reuse of these residues allows manufacturers to reduce the consumption of natural resources and minimize the production of wastes. According to the Directive (EU) 2018/851 (amending Directive 2008/98/EC) for the use of recycled materials in construction, the main purpose of this study was to favor the reuse of steel industry residues rather than landfill disposal. The use of slag in construction dates back to the Romans, who used crushed slags from the crude iron production to build their roads. Nowadays, slags are still used to build roads due to their excellent mechanical strength performance [2], but their use is not limited to roads anymore and slag aggregates are widely used in all kinds of civil works [3,4]. 
The steel is made in integrated steel plants using a basic oxygen furnace (BOF) or an electric arc furnace (EAF) process. The technology of the electric furnace has established itself due to the lower complexity of the production cycle, the increased availability of steel scrap, and the lower $\mathrm{CO}_{2}$ emissions [5]. Steel slag is produced during the separation of molten steel from impurities in steel furnaces. The slag appears as a heterogeneous solution of silicon dioxide and calcium-iron oxides that solidify during cooling. These characteristics make it suitable for the substitution of aggregates in the construction sector, such as aggregate in road base or sub-base layers, asphalt mixtures, concrete production, or for soft clay stabilization. In 2018, the total production of crude steel in Europe was 167.1 million tons, of which 69.5 million tons derived from EAF process $(41.5 \%)$ [6]. In the same period, the Italian crude steel production was 24.5 million tons, of which 20.0 million tons (81.6\%) derived from EAF processes [7]. Liu Chunlin et al. [8], Subathra Devi et al. [9], and Rondi et al. [10] stated that steel slags, as the main by-products in the crude steel production process, represent $15-20 \%$ of the entire crude steel production (weight/weight). This resulted in an average EAF steel slag production of about 13.9 and 3.5 million tons in Europe and Italy in 2018, respectively.

In order to avoid landfilling and to reduce the depletion of natural resources due to the fast pace of construction activities, a correct management of EAF steel slags is required by evaluating the possible release of contaminants into the surrounding environment and the technical feasibility for their use in the construction sector [11]. Several studies have been performed on the properties and the use of EAF steel slags in concrete [12,13]. Many authors found that the release of pollutants from EAF slags is generally below the regulatory limits [14,15]. On the contrary, authors such as Mombelli et al. [16] and Rondi et al. [10] detected high concentrations of $\mathrm{Ba}, \mathrm{Cr}$, and $\mathrm{V}$ in EAF steel slags when subjected to leaching tests. Other authors, such as Ledesma et al. [17], evaluated the potential reuse of EAF dust in mortar. The results highlighted that $\mathrm{Se}, \mathrm{Mo}, \mathrm{Cd}, \mathrm{Pb}$, and $\mathrm{Cl}$ anion were the most conflictive elements; this phenomenon was particularly evident in the finest grain size fraction due to the higher specific surface [18,19]. Some studies have also been developed on the potential ecotoxicity and genotoxicity of steel slags [20]. The authors, by an integrated chemical-biological approach applied to plant, animal organisms, bacteria, and human cells, demonstrated the low toxicity of steel slags, ensuring the feasibility of their potential use as recycled material.

The possibility of using EAF positively in concrete has also been demonstrated by many authors $[8,9,11,18,21-29]$. For instance, Manso et al. [18] demonstrated that the definition of the optimal grading curve is a key parameter to improve the workability and the mechanical properties of the concrete produced. In particular, the authors suggested that the use of steel slags with a size of $0-20 \mathrm{~mm}$ and the addition of a suitable proportion of natural aggregates to adjust the grading curve may improve the concrete workability. This was also observed by other investigations [11]. On the other hand, the inclusion of EAF steel slags in concrete mixtures can sometimes lead to a decrease in workability due to the greater water absorption of the slag. In particular, EAF steel slags evidence higher water absorption (2-5\%) when compared to the corresponding values of natural coarse aggregates $[9,22,26,29]$. This is due to their rough and porous surface, as demonstrated by $\mathrm{Abu}$-Eishah et al. [11]. In this context, Subathra et al. [9] investigated the use of fine and coarse steel slag as aggregate in concrete. For a constant water/cement ratio (w/c), the results showed a high water absorption by steel slag and a drastic reduction in the workability of the concrete mixtures. In particular, the replacement of $30 \%$ of coarse natural aggregates with steel slags ( $5 \%$ of water absorption) decreased the concrete workability by about $20 \%$. This can be easily overcome by adding proper amount of superplasticizer in the mixture [26]. The studies also revealed improvement in mechanical properties of the hardened concrete [29]. In particular, the authors [23,26] observed that the compressive strength increased up to $45 \mathrm{MPa}(50 \%$ more than a conventional concrete with the same characteristics) when the concrete mixture was realized, with $40 \%$ of steel slag replacement and 0.55 water/cement ratio. Other studies $[10,24,27]$ generally showed good results 
regarding tensile strength, hygrometric shrinkage, and elastic modulus of the conglomerate made with EAF steel slags. In particular, Santamaria et al. [21] highlighted that the addition of fly ash in concrete mixture can slightly increase the shrinkage values, a phenomenon that can be mitigated by the presence of steel slag (due to its volume expansion). Moreover, the drying shrinkage of steel slag concrete after the same curing time ( 90 days) presented values very close to reference concrete, indicating that steel slag has a small influence on the concrete shrinkage, as demonstrated by Qiang et al. [28]. The main problem concerns the durability of the EAF steel slag concrete $[18,27]$. Abu et al. [11] pointed out that water is one of the most frequent causes of concrete deterioration. In fact, when subjected to different wetting-drying cycles, an evident degradation of the samples was detected, as reported by Santamaria et al. [21]. The resulting compressive strength, following the aforementioned wetting-drying cycles, showed an evident loss of strength ranging from $2 \%$ to $40 \%$ of the initial compression strength. The authors also highlighted that, in terms of durability, a suitable fines content (amounting to $15-16 \%$ by aggregate volume) seems to be a key variable in this durability tests.

According to the studies available in the literature, the present study aimed to clarify and support the data obtained over the years. In particular, in order to evaluate the environmental performance of steel slag as a secondary raw material, the batch leaching test (UNI EN 12457-2) was applied, as well as the evaluation of the potential toxic and mutagenic effect on the ecosystem.

The aggregates, which represent about $70 \%$ of the volume of materials used for concrete production [9], usually derive from natural resources (gravel, sand, stone, etc.); they provide a rigid skeleton structure and reduce the space occupied by the cement paste in the conglomerate. Therefore, the aim of the study was to investigate the mechanical and durability properties of concrete mixtures, in which 30\% of natural aggregates were replaced with EAF steel slags (weight/weight). The mixtures were then characterized both in the fresh (i.e., slump test) and hardened state (i.e., compression strength, indirect tensile strength, hygrometric shrinkage, elastic modulus).

\section{Materials and Methods}

\subsection{Materials}

\subsubsection{EAF Steel Slag}

EAF is used for the steel production from metallic scraps. Scrap-based steel accounts for about $25 \%$ of the global steel production [6]. The scrap is melted by an electric arc constituted by three graphite electrodes that, through a violent thermal action, bring the scrap from the solid state to the liquid one. As the slags are lighter than the liquid metal, they float and can be easily removed. The EAF slag derive, therefore, from the rapid cooling of the oxidized and superficial liquid from about $1600^{\circ} \mathrm{C}$ to room temperature, followed by a double crushing and sieving phase.

The slag from carbon steel production (EAF-C) used for the present research work was supplied by a steel plant located in Lombardy (Province of Brescia) and catalogued with EWC code 100202 (i.e., solid waste of the untreated steel industry stored in open piles on a waterproofed surface) (Figure 1). Different sizes of slag were used depending on the type of mixture designed. Three different grain size fractions were adopted, respectively: 5-10 mm, 10-16 mm, and 16-20 mm. For the leaching test, the slag samples were further crushed and sieved up to a diameter $<4 \mathrm{~mm}$. 


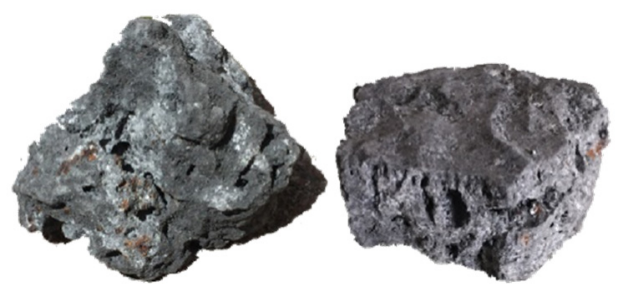

Figure 1. Electric arc furnace (EAF) steel slag used.

\subsubsection{Concrete Mixtures Made with EAF Steel Slag}

Conventional concrete is composed of aggregates (constituting $60-80 \%$ of the total volume), cement, water, air, and other chemical additives. The concrete mixtures herein considered were designed with $30 \%$ by weight of EAF steel slag as coarse aggregate $(\mathrm{d} \geq 5 \mathrm{~mm})$ in order to evaluate the concrete performance behavior with a partial substitution of natural aggregates. In particular, the steel slag had a maximum diameter of $20 \mathrm{~mm}$.

The grain size distribution was chosen in order to better reproduce the distribution curve of Bolomey, which represents a compromise between minimization of voids and improvement of workability. The water/cement ratio (w/c) was 0.48 . Furthermore, an additive superplasticizer was used in the concrete mixture in order to guarantee the target workability by considering that part of the mixing water was absorbed by EAF steel slag. The concrete density was about $2470 \mathrm{~kg} / \mathrm{m}^{3}$, comparable to that of a traditional concrete. The mix composition is shown in Table 1 .

Table 1. Composition of concrete with EAF steel slag.

\begin{tabular}{ccc}
\hline Component & $\mathbf{( k g / \mathbf { m } ^ { 3 } )}$ & $\mathbf{( L / \mathbf { m } ^ { 3 } )}$ \\
\hline Portland cement CEM II/A-LL 42.5R & 400 & 127 \\
Water & 190 & 190 \\
Aggregates & 1879 & 659 \\
Fluidifying additive & 4.0 & 3.7 \\
Mass density & \multicolumn{2}{c}{$2470\left[\mathrm{~kg} / \mathrm{m}^{3}\right]$} \\
Water/cement ratio (w/c) & \multicolumn{2}{c}{0.48} \\
Steel slag replacement & $30 \%$ & \\
\hline
\end{tabular}

\subsection{Experimental Methods}

\subsubsection{EAF Steel Slag}

In the environmental context, leaching tests simulate the process of transferring chemical constituents from a solid particle to an aqueous solution (demineralized water) in contact with the particle. The release of contaminants from the steel slag was evaluated according to the batch leaching test (UNI EN 12457-2) [30] and compared with natural aggregates. The eluate obtained was chemically characterized, detecting the parameters required by the Ministerial Decree 186/2006 (M.D. 186/2006) [31] for the recovery and reuse of special waste, in this case, steel slag.

Six liters of eluate were produced in 7 polyethylene bottles (PE) with a liquid/solid ratio of $10 \mathrm{~L} / \mathrm{kg}$ and demineralized water at $\mathrm{pH}=6.2$ and conductivity $3.8 \mu \mathrm{S}$. The bottles have been placed in the Rotax, a device that keeps them rotating at a speed of 10 revolutions/minute for $24 \mathrm{~h}$, according to the test procedure. The eluate obtained was filtered at $0.45 \mu \mathrm{m}$ using a vacuum filtration device and characterized from a chemical point of view, detecting the parameters required by the M.D 186/2006.

An ionic chromatography system (Dionex, model ICS 1000) was used to detect the concentrations of nitrates, fluorides, sulphates, and chlorides. The metal concentrations were instead measured using an optical plasma ICP spectrometer (PerkinElmer, Optima 2000 DV model). Finally, the analysis of cyanides was carried out using a colorimetric method (Nanocolor $400 \mathrm{D}$ ). 


\subsubsection{Concrete Mixtures Made with EAF Steel Slag}

The experimental research deals with the mechanical characterization of fresh and hardened concrete. The experimental tests were carried out at the Materials Testing Laboratory of the University of Brescia. The fresh concrete was cast into the mold after mixing and was compacted by immersion vibrator up to the maximum level. After that, the samples were stored in a fog room at a temperature of $20{ }^{\circ} \mathrm{C}$ and $95 \%$ relative humidity. Workability was measured by slump test according to EN 12350-2 [32].

The uniaxial compression strength was evaluated on 18 cubic samples with a side of $150 \mathrm{~mm}$ at different curing times, according to the EN 12390-3 [33]. The tests were carried out with the Controls Autocomp machine $(3000 \mathrm{kN})$. Four of the 18 cubic specimens were subjected to drying cycles in an oven at $110{ }^{\circ} \mathrm{C}$ for $8 \mathrm{~h}$ and hydration in water at room temperature for the remaining $16 \mathrm{~h}$. Indirect tensile strength was studied on 3 cylindrical samples with diameter of $100 \mathrm{~mm}$ after 28 curing days, according to EN 12390-6 [34].

Accelerated ageing tests and hygrometric shrinkage tests were performed on 2 prismatic beams with a square base of $80 \times 80 \mathrm{~mm}$ and a length of $285 \mathrm{~mm}$, then stored in a moist room at $20^{\circ} \mathrm{C}$ with $50 \%$ relative humidity, according to American ASTM C157/C $157 \mathrm{M}-08$ standards [35]. The monitoring of the hygrometric shrinkage was performed day by day up to 50 days of samples curing.

Finally, the elastic modulus was measured on 3 cylindrical specimens, according to EN 12390-13 [36]. The machine used for the test was the Metrocom press model MI10-100 kN, equipped with manual load control. Table 2 summarizes the tests developed on concrete samples.

Table 2. Tests performed on fresh and hardened concrete samples.

\begin{tabular}{cc}
\hline Test & Number and Size of Samples \\
\hline Workability & Cone of Abrams \\
Uniaxial compression & 18 cubic samples $(150 \times 150 \times 150 \mathrm{~mm})$ \\
Indirect tensile strength & 3 cylindrical samples $(\varnothing 100 \mathrm{~mm} ; \mathrm{h}=200 \mathrm{~mm})$ \\
Hygrometric shrinkage & 2 prismatic beams $(80 \times 80 \times 285 \mathrm{~mm})$ \\
Elastic modulus & 3 cylindrical samples $(\varnothing 100 \mathrm{~mm} ; \mathrm{h}=200 \mathrm{~mm})$ \\
\hline
\end{tabular}

\section{Results and Discussion}

\subsection{EAF Steel Slag Characterisation}

Leaching Behavior

The environmental behavior according to the leaching tests performed on the EAF steel slags showed release levels of pollutant elements below the limits imposed by the M.D. 186/2006, as shown in Table 3. Although the decree only concerns nonhazardous waste, and therefore does not affect quarry aggregates, it is necessary to include data from a natural material in order to establish the comparison between leaching levels recorded in the material in study (EAF steel slag) and the natural one (natural aggregate), since the type of unbound use could be the same for both tested aggregates. 
Table 3. Leachate concentrations from EAF steel slag and natural aggregate.

\begin{tabular}{ccccc}
\hline Parameter & Unit & EAF Steel Slag & Natural Aggregate & Limits of M.D. 186/2006 \\
\hline pH & - & 10.4 & 8.4 & $5.5-12$ \\
Nitrates & $\mathrm{mg} / \mathrm{L}$ & $<1$ & 1.1 & 50 \\
Fluorides & $\mathrm{mg} / \mathrm{L}$ & 0.15 & $<0.1$ & 1.5 \\
Sulphates & $\mathrm{mg} / \mathrm{L}$ & 5.7 & 0.86 & 250 \\
Chloride & $\mathrm{mg} / \mathrm{L}$ & 1.6 & 1.6 & 100 \\
Cyanide & $\mu \mathrm{g} / \mathrm{L}$ & $<5$ & $<10$ & 50 \\
Barium & $\mathrm{mg} / \mathrm{L}$ & 0.29 & 0.021 & 1 \\
Copper & $\mathrm{mg} / \mathrm{L}$ & $<0.01$ & $<0.01$ & 0.05 \\
Zinc & $\mathrm{mg} / \mathrm{L}$ & $<0.01$ & $<0.01$ & 3 \\
Berillium & $\mu \mathrm{g} / \mathrm{L}$ & $<0.01$ & $<10$ & 10 \\
Cobalt & $\mu \mathrm{g} / \mathrm{L}$ & $<10$ & $<10$ & 250 \\
Nickel & $\mu \mathrm{g} / \mathrm{L}$ & $<5$ & $<10$ & 10 \\
Vanadium & $\mu \mathrm{g} / \mathrm{L}$ & 220 & 23 & 250 \\
Arsenic & $\mu \mathrm{g} / \mathrm{L}$ & $<10$ & 18 & 50 \\
Cadmium & $\mu \mathrm{g} / \mathrm{L}$ & $<1$ & $<4$ & 5 \\
Total chromium & $\mu \mathrm{g} / \mathrm{L}$ & 5 & $<10$ & 50 \\
Lead & $\mu \mathrm{g} / \mathrm{L}$ & 12 & $<10$ & 50 \\
Selenium & $\mu \mathrm{g} / \mathrm{L}$ & $<5$ & $<10$ \\
Mercury & $\mu \mathrm{g} / \mathrm{L}$ & $<1$ & $\mathrm{n} . \mathrm{d}^{(1)}$ & 10 \\
Asbestos & $\mathrm{mg} / \mathrm{L}$ & $\mathrm{n} . \mathrm{d}^{(1)}$ & $<15$ & 30 \\
COD & $\mathrm{mg} / \mathrm{L}$ & $<15$ & & 30 \\
\hline
\end{tabular}

(1) n.d: not detected.

Overall, compared to natural aggregate, the steel slag eluate had higher concentrations of constituents, except for nitrates and arsenic. For both materials the $\mathrm{pH}$ was alkaline, with a lower value in the eluate from natural aggregate.

According to leaching data obtained from eluates from granular samples of EAF steel slag and the natural sample used as control, concentrations of pollutants were lower than the legal limits indicated by the M.D. 186/2006. The measured levels (expressed in $\mathrm{mg} / \mathrm{L}$ and $\mu \mathrm{g} / \mathrm{L}$ ) were close to the limit only for vanadium and barium (data consistent with previous works about leaching behavior on EAF steel slag [10]). Results prove that the tested material complies with current legislation and can be used for concrete manufacturing as a partial substitution of natural coarse aggregates contributing to a sustainable concrete production.

\subsection{EAF Slag Concrete Characterisation}

In order to evaluate the mechanical behavior of concrete mixtures made with EAF steel slag, several tests on fresh and hardened concrete were developed.

\subsubsection{Workability}

At the end of the mixing process, the fresh concrete must have a homogeneous mass that is able to guarantee workability as well as mechanical resistance in its hardened state.

Fresh concrete had a slump of $140 \mathrm{~mm}$, which identified it as a S3 consistency class (defined as "semi-fluid") according to EN 206 [37]. It was found that the use of steel slag with a maximum diameter higher than $20 \mathrm{~mm}$ caused an undesired impact on workability. In particular, during the production of preliminary concrete mixtures, the use of steel slag with a maximum diameter of $31.5 \mathrm{~mm}$ caused a slag segregation in the concrete mixture. For this reason, the maximum particle size was reduced to $20 \mathrm{~mm}$.

However, concrete with steel slag is suitable for usual reinforced concrete structures and requires an accurate vibration time.

\subsubsection{Compression Strength}

Compression strength was measured on eighteen cubic specimens with a side of $150 \mathrm{~mm}$ (Figure 2). The samples were tested after 3, 7, 14, 21, 28, 70, and 90 days of curing in order to evaluate the compression strength variation over time. After 28 days a significant fraction of the final resistance was obtained. 


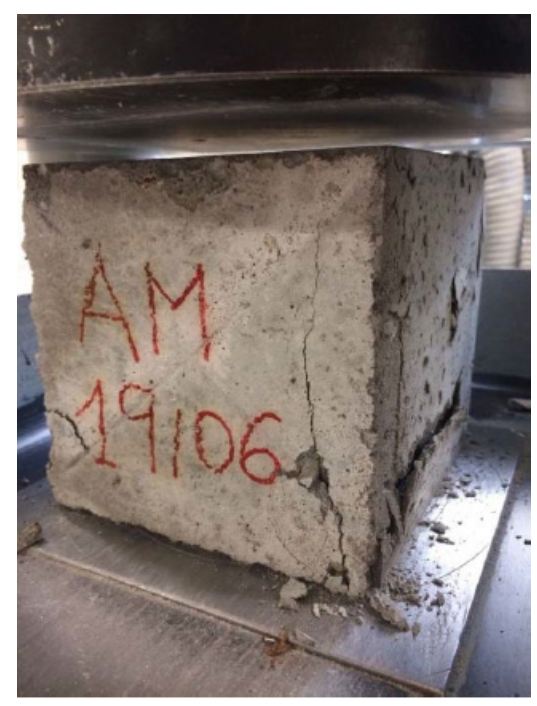

Figure 2. Compression strength test on cubic samples.

All the failure modes of the cubic samples under uniaxial compression were satisfactory. The average compression strength values of both the 16 cubic samples and the four samples subjected to wetting and drying cycles (the strength for these samples was determined only at 28 and 90 curing days) are shown in Table 4 . It is worth observing that compression strength continuously increases in the EAF slag concrete samples. This behavior is attributable to the strong bond between the cement paste and the steel slag used, characterized by rough surface and angular shape. A significant loss of strength was evident in all samples subjected to wetting and drying cycles, with a loss of about $25 \%$ after the treatment. The damage was produced by two combined effects: thermal dilation and contraction and shrinkage due to moisture variation, as demonstrated in [19]. In particular, after the process, all the samples showed a white powder outcrops on the surface, clearly identifiable as calcium and magnesium hydroxides. This efflorescence, composed by dissolved salts transported to the surface of the sample by water evaporation [38], showed no detrimental effects and did not affect the loss in compressive strength.

Table 4. Compression strength of cubic samples at different curing time.

\begin{tabular}{ccc}
\hline \multirow{2}{*}{ Curing Days } & \multicolumn{2}{c}{ Average Value (MPa) } \\
\cline { 2 - 3 } & Monotonic Loads & Wet-Dry Cyclic Loads \\
\hline 3 & 40.5 & - \\
7 & 45.3 & - \\
14 & 48.0 & - \\
21 & 46.3 & 37.8 \\
28 & 50.6 & - \\
70 & 52.8 & 34.5 \\
\hline 0 & 52.3 & \\
\hline
\end{tabular}

As stated by Pellegrino et al. [38], the influence of wetting and drying cycles on the compressive strength is generally similar for natural and steel slag concrete. In particular, a loss of strength of $15 \%$ was recorded for the traditional concrete, while a loss of strength of $22 \%$ was recorded for the steel slag concrete. These results are in line with those obtained from this study.

Figure 3 shows the development of the cubic compression strength vs. time and the comparison between experimental data and the reference curve proposed by Eurocode 2 [39] for normal concrete in standard conditions (temperature of $20^{\circ} \mathrm{C}$, relative humidity (RH) larger than 95\%). 


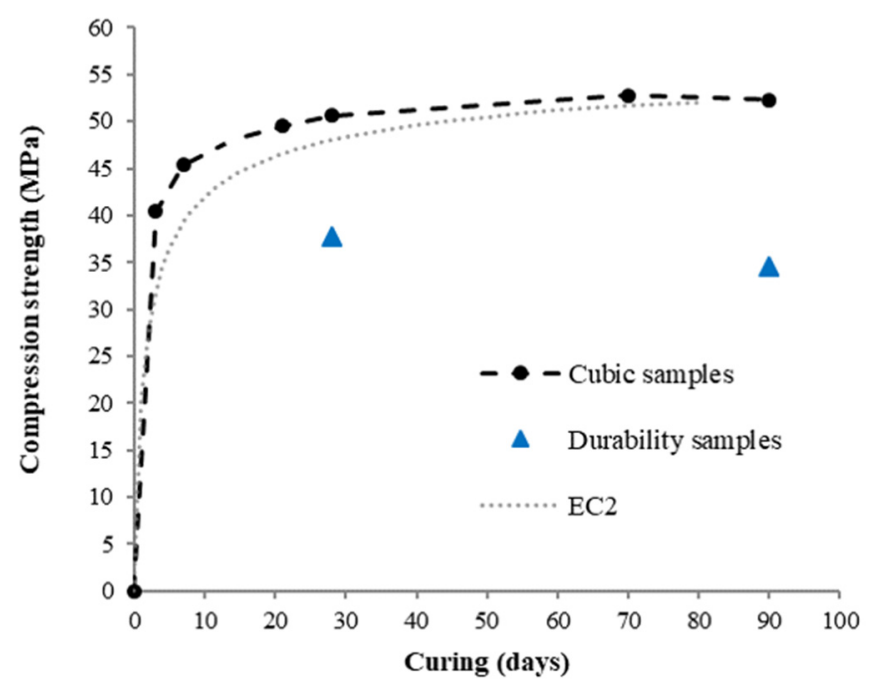

Figure 3. Results from compression tests at different curing time.

Since the number of tests after 28 days of curing was not sufficient to determine a statistical data, the characteristic strength (fck) was evaluated as [40]:

$$
\mathrm{fck}=\mathrm{fcm}-8[\mathrm{MPa}]
$$

where fck is the characteristic cylindrical compressive strength and $\mathrm{fcm}$ is the mean cylindrical compressive strength of concrete. According to the experimental results obtained from the compression tests, concrete with EAF slags can be classified as C32/40.

\subsubsection{Indirect Tensile Strength}

Concrete structures are highly exposed to tensile cracking due to the applied loads. A cylindrical sample was loaded diametrically and uniformly across the circular cross section. To allow the uniform distribution of the applied load, plywood strips were placed between the sample and the load plates of the testing machine. The load caused a tensile deformation perpendicular to the loading direction, which produced a tensile failure. So, the concrete samples split into two halves due to the indirect tensile stress, as shown in Figure 4. The tensile load can be calculated from the formula as:

$$
\sigma c=2 \mathrm{P} /(\pi \mathrm{hd}),
$$

where $\mathrm{P}=$ compressive load at failure $\mathrm{h}=$ length of the cylinder, and $\mathrm{d}=$ diameter of the cylinder.

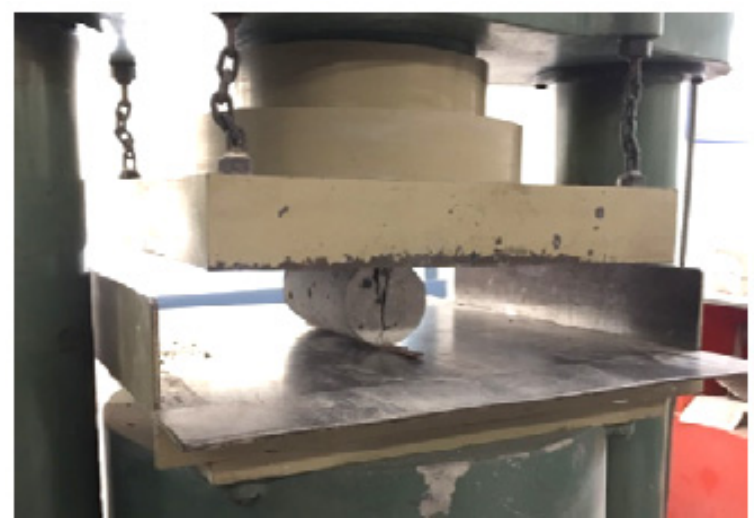

Figure 4. Sample failure mode. 
Sample 1 showed lower resistance values, so it was considered as an anomalous sample. Table 5 shows the experimental results obtained; it can be noticed that the average tensile strength (i.e., $3.62 \mathrm{MPa}$ ) represented $7 \%$ of the compressive strength calculated at the same curing period.

Table 5. Indirect tensile strength values of the analysed samples.

\begin{tabular}{ccc}
\hline Sample & Failure Load $\mathbf{( k N )}$ & Indirect Tensile Strength at 28 Days (MPa) \\
\hline 1 & 76.5 & 2.43 \\
2 & 121.6 & 3.87 \\
3 & 105.9 & 3.37 \\
\hline
\end{tabular}

\subsubsection{Hygrometric Shrinkage}

The test was performed to measure the axial dimensional shrinkage of concrete samples during the hardening process in a curing room. According to ASTM C157 standard [35], steel pins were glued on the head surfaces of the sample in order to measure the dimensional changes of samples properly stored in specified temperature and humidity conditions $\left(20^{\circ} \mathrm{C}\right.$ and $50 \%$ relative humidity). The measurement of the variation of the specimen length allowed us to assess the volumetric expansion/contraction of concrete. The test device requires a reference bar made with nonabrasive and anti-absorbing material that does not vary its size over time.

Figure 5 shows the trend over time of the sample's deformation induced by the hygrometric shrinkage and the reference curves proposed by Ministerial Decree 17/01/2018 [41] and Eurocode 2 [40].

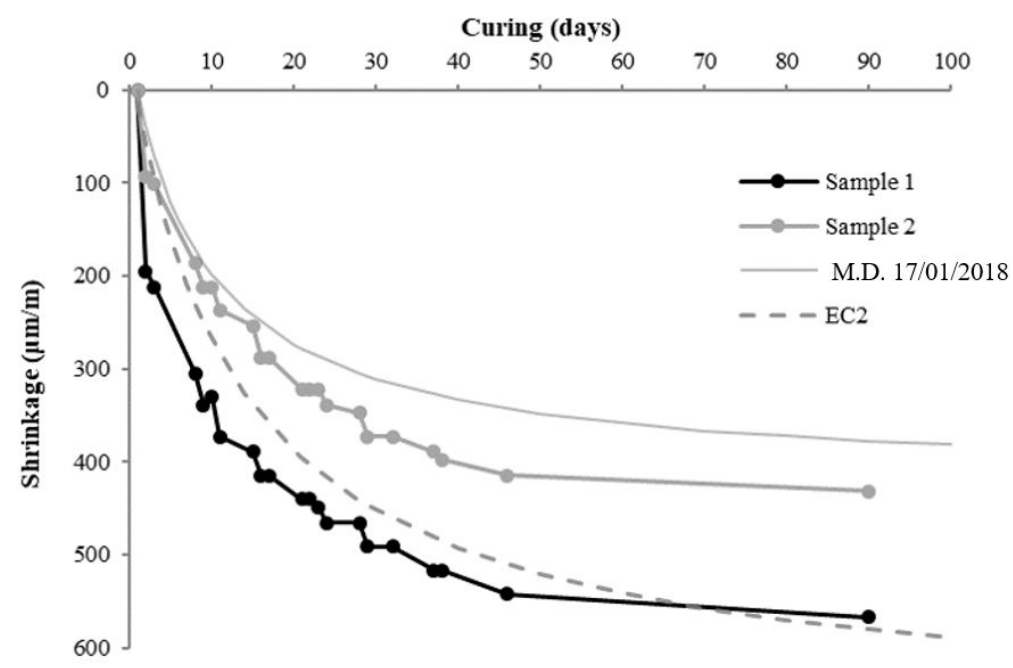

Figure 5. Shrinkage tests on prismatic specimens at different curing days.

Analyzing the data obtained during 90 days of curing, the two samples reached asymptotic values of about $400 \mu \mathrm{m} / \mathrm{m}$ and $550 \mu \mathrm{m} / \mathrm{m}$, respectively, which are typical values for a normal concrete.

\subsubsection{Elastic Modulus}

The concrete elastic modulus is directly related to the elastic modulus of the aggregates and the cement matrix. In this study, the elastic modulus was determined according to EN 12390-13 [36]. Before the test, the samples were stabilized at room temperature and humidity; conditions that were maintained throughout the duration of the test. Each sample was subjected to three increasing loading/unloading cycles, the values of the stresses applied by the press varied from $\mathrm{F} / 10$ to a maximum value equal to $\mathrm{F} / 3$, until instrumentation stabilization. 
The different loading and unloading cycles performed for each sample as well as the stress-strain curves with the corresponding trend line for steel slag concrete are shown in Figure 6.
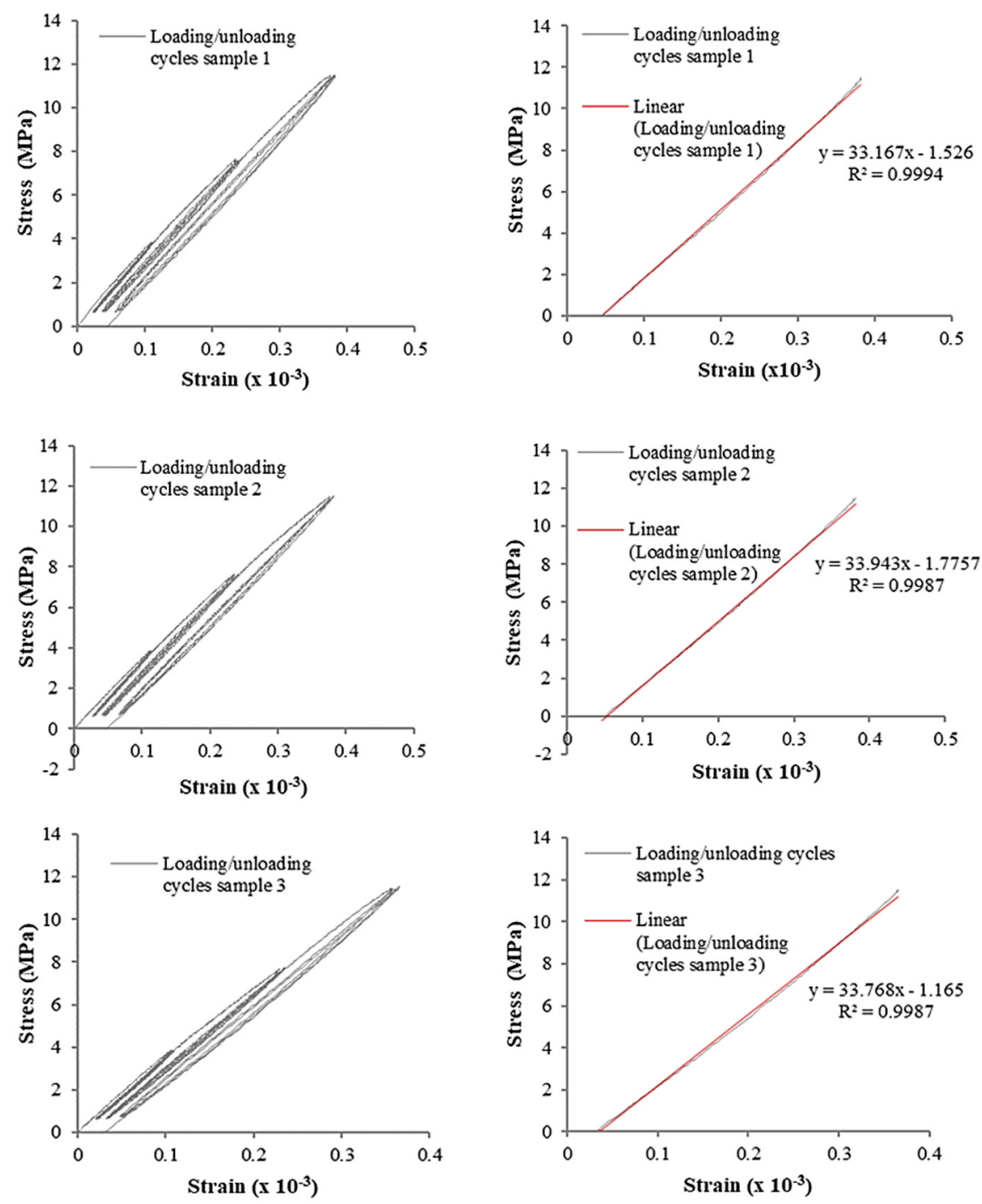

Figure 6. Load-unload cycles and values of the elastic modulus for the 3 different samples.

The experimental values show a mean elastic modulus value of about $34 \mathrm{GPa}$; this result shows that the stiffness contribution provided by the slag is compatible with that of a traditional concrete (about 35 GPa for a C35/45, according to Eurocode 2 [40]).

\section{Recycled Concrete as a Sustainable Building Material}

The present research work focused on the evaluation of the environmental and technical feasibility of using an industrial by-product (EAF steel slag) as aggregate in concrete. Life-cycling is a concept that involves the environmental impacts during the entire life cycle of a product (as a construction material), from the extraction of resources for its manufacturing to their disposal phase. The green philosophy of the present research work was to contribute and promote waste prevention through the reuse and recovery of industrial by-products, with waste disposal as a last resort.

In addition to promoting material recovery, environmentally sustainable concrete from secondary materials also has the potential to save energy and $\mathrm{CO}_{2}$ emissions compared to more traditional concrete [39]. Generally, Portland cement was found to be the main 
source of $\mathrm{CO}_{2}$ emissions produced by traditional concrete mixtures, being responsible for $74 \%$ to $81 \%$ of total $\mathrm{CO}_{2}$ emissions. At the same time, coarse aggregates represented the second main source of $\mathrm{CO}_{2}$ emissions and were responsible for $13 \%$ to $20 \%$ of the total $\mathrm{CO}_{2}$ emissions produced by concrete production [42]. Otherwise, fine aggregates generated less equivalent $\mathrm{CO}_{2}$ since they were not crushed.

In this context, the use of industrial by-products such as slags from steelworks as coarse aggregates in concrete production can, therefore, significantly contribute to increasing the environmental sustainability of the entire economic sector. At the same time, as also demonstrated by the experimental results obtained in this study, the use of EAF steel slags, in comparison with other recycled materials such as construction and demolition waste, is desirable in concrete structures to get better mechanical performance than traditional concrete.

However, regardless the analysis of the physical and mechanical properties of the recycled materials used in the concrete, it is essential to evaluate their pollutant potential due to the presence of hazardous compounds that may be released into the environment. The release level of these hazardous chemical elements must be evaluated according to the leaching test, which is a useful analytical tool [43]. In the present study, no element listed in the M.D. 186/2006 regulation exceeded the legal limit, so the environmental feasibility of EAF steel slag for being used for concrete was demonstrated. In that sense, in the research field on recycled building materials, combining the study of mechanical properties, which ensures the correct behavior of materials in structures, with the environmental assessment, which guarantees the environment safety and health, ensures to achieve the green policies that European Union promotes in key areas, as is the case of construction sector.

\section{Conclusions}

The present work investigated the influence of EAF steel slag as a partial substitute of natural coarse aggregate in concrete production. Based on the experimental results, the following conclusions can be drawn.

- The release of pollutants from steel slag was acceptable. The eluates produced widely respected all the standard limits established by M.D. 186/2006 [31]. Only vanadium showed a concentration value close to the limit $(220 \mu \mathrm{g} / \mathrm{L})$.

- The use of steel slag with a maximum diameter higher than $20 \mathrm{~mm}$ had an undesired impact on concrete workability (steel slag segregation). In light of this, it is recommended to use this maximum grain size to prevent any difficulties in the subsequent concrete mixing.

- $\quad$ The average compressive strength of concrete mixtures made with EAF steel slags increased up to $53 \mathrm{MPa}$ at 90 days of curing. This can be ascribed to the strong bond between cement/mortar particles and EAF steel slags, as well as to the porous and rough surface of the steel slag. However, tests up to 1 year of curing are foreseen to prevent any unexpected decrease in load bearing capacity. Based on the results obtained, the concrete could be classified as $\mathrm{C} 32 / 40$.

- The concrete density was about $2470 \mathrm{~kg} / \mathrm{m}^{3}$, which is comparable to the traditional concrete density.

- Samples subjected to wetting-drying cycles showed a significant compressive strength reduction due to the consecutive thermal variations. In particular, after 28 days of curing, the tested samples exhibit a loss of strength of about $25 \%$ (range from $51 \mathrm{MPa}$ to $38 \mathrm{MPa}$ ).

- $\quad$ The concrete mixtures showed an average indirect tensile strength of $3.62 \mathrm{MPa}$, which represented about $7 \%$ of the relative compressive strength.

- Hygrometric shrinkage of steel slag concrete developed quickly during the first days due to the effect of the high water absorption of EAF steel slag, and slowly in the following days, until reaching a horizontal asymptote of about $500 \mu \mathrm{m} / \mathrm{m}$.

- The elastic modulus of concrete mixtures was about $34 \mathrm{GPa}$. Although steel slag has internal pores, the elastic modulus of the concrete made with EAF steel slag was closer to 
that of traditional concrete. Therefore, the effect of the aggregate type on these coefficients was negligible and these results agree with those obtained by most authors.

This experimentation showed good technical and environmental results for the use of EAF steel slag as coarse aggregate in concrete production. In particular, EAF steel slag can be successfully used to replace gravel in concrete without affecting the concrete properties. In fact, despite the increase in density, the use of steel slags as partial replacement of natural aggregates allows users to obtain concrete with good workability and mechanical properties.

Author Contributions: The following contributions were made by each author: conceptualization, G.P., S.S., and L.C.; methodology, G.P., S.S., L.C., and A.D.; writing-original draft preparation, A.D.; writing-review and editing, A.D., G.P., S.S., L.C., and A.P.G.; visualization, A.D., G.P., S.S., L.C., and A.P.G.; supervision, G.P., S.S., and L.C.; project administration, G.P., S.S. and L.C. All authors have read and agreed to the published version of the manuscript.

Funding: This research received no funding.

Institutional Review Board Statement: Not applicable.

Informed Consent Statement: Not applicable.

Data Availability Statement: Data sharing not applicable.

Acknowledgments: The authors wish to thank Alfa Acciai steelwork for supplying EAF steel slags during the research work development.

Conflicts of Interest: The authors declare no conflict of interest.

\section{References}

1. Vishwakarma, V.; Uthaman, S. Environmental impact of sustainable green concrete. In Smart Nanoconcretes and Cement-Based Materials: Properties, Modelling and Applications; Elsevier Inc.: Amsterdam, The Netherlands, 2019; pp. 241-255. ISBN 9780128178553.

2. Ferreira, V.J.; Sàez-De-Guinoa Vilaplana, A.; Garcìa-Armingol, T.; Aranda-Usòn, A.; Lausìn-Gonzàlez, C.; Lòpez-Sabiròn, A.M.; Ferreira, G. Evaluation of the steel slag incorporation as coarse aggregate for road construction: Technical requirements and environmental impact assessment. J. Clean. Prod. 2016, 130, 175-186. [CrossRef]

3. Ahmedzade, P.; Sengoz, B. Evaluation of steel slag coarse aggregate in hot mix asphalt concrete. J. Hazard. Mater. 2009, 165, 300-305. [CrossRef] [PubMed]

4. Yong-Feng, D.; Tong-Wei, Z.; Yu, Z.; Qian-Wen, L.; Qiong, W. Mechanical behaviour and microstructure of steel slag-based composite and its application for soft clay stabilisation. Eur. J. Environ. Civ. Eng. 2017, 1-16. [CrossRef]

5. Morfeldt, J.; Nijs, W.; Silveira, S. The impact of climate targets on future steel production-An analysis based on a global energy system model. J. Clean. Prod. 2015. [CrossRef]

6. World Steel Association Statistics_Crude Steel Production. Available online: https://www.worldsteel.org/en/dam/jcr:5001 dac8-0083-46f3-aadd-35aa357acbcc/SSY\%25202020_concise\%2520version.pdf (accessed on 7 January 2021).

7. Federacciai. The Italian Steel Industry Key Statistics; Federacciai: Milan, Italy, 2019.

8. Liu, C.; Zha, K.; Chen, D. Possibility of concrete prepared with steel slag as fine and coarse aggregates: A preliminary study. Procedia Eng. 2011, 24, 412-416.

9. Subathra Devi, V.; Gnanavel, B.K. Properties of concrete manufactured using steel slag. Procedia Eng. 2014, 97, 95-104. [CrossRef]

10. Rondi, L.; Bregoli, G.; Sorlini, S.; Cominoli, L.; Collivignarelli, C.; Plizzari, G. Concrete with EAF steel slag as aggregate: A comprehensive technical and environmental characterisation. Compos. Part B Eng. 2016, 90, 195-202. [CrossRef]

11. Abu-Eishah, S.I.; El-Dieb, A.S.; Bedir, M.S. Performance of concrete mixtures made with electric arc furnace (EAF) steel slag aggregate produced in the Arabian Gulf region. Constr. Build. Mater. 2012, 34, 249-256. [CrossRef]

12. Lopez, F.A.; Lopez-Delgado, A.; Balcazar, N. Physico-chemical and mineralogical properties of EAF and AOD slags. Assoc. Ital. Metall. 1997, 53, 417-426.

13. Yildirim, I.Z.; Prezzi, M. Chemical, mineralogical, and morphological properties of steel slag. Adv. Civ. Eng. 2011, 2011. [CrossRef]

14. Teo, P.T.; Anasyida, A.S.; Basu, P.; Mohd Sharif, N. Chemical, Thermal and Phase Analysis of Malaysia's Electric Arc Furnace (EAF) Slag Waste. Mater. Sci. Forum 2016, 840, 399-403. [CrossRef]

15. Sorlini, S.; Sanzeni, A.; Rondi, L. Reuse of steel slag in bituminous paving mixtures. J. Hazard. Mater. 2012, 209-210, 84-91. [CrossRef] [PubMed]

16. Mombelli, D.; Mapelli, C.; Barella, S.; Di Cecca, C.; Le Saout, G.; Garcia-Diaz, E. The effect of chemical composition on the leaching behaviour of electric arc furnace (EAF) carbon steel slag during a standard leaching test. J. Environ. Chem. Eng. 2016, 4, 1050-1060. [CrossRef]

17. Ledesma, E.F.; Lozano-Lunar, A.; Ayuso, J.; Galvín, A.P.; Fernández, J.M.; Jiménez, J.R. The role of pH on leaching of heavy metals and chlorides from electric arc furnace dust in cement-based mortars. Constr. Build. Mater. 2018, 183, 365-375. [CrossRef] 
18. Manso, J.M.; Polanco, J.A.; Losañez, M.; González, J.J. Durability of concrete made with EAF slag as aggregate. Cem. Concr. Compos. 2006, 28, 528-534. [CrossRef]

19. Barella, S.; Gruttadauria, A.; Magni, F.; Mapelli, C.; Mombelli, D. Survey about Safe and Reliable Use of EAF Slag. ISIJ Int. 2012, 52, 2295-2302. [CrossRef]

20. Benassi, L.; Alias, C.; Feretti, D.; Gelatti, U.; Piovani, G.; Zerbini, I.; Sorlini, S. Ecotoxicity and Genotoxicity of Steel Slags: Preliminary Results. Detritus 2019. [CrossRef]

21. Santamaría, A.; Orbe, A.; San José, J.T.; González, J.J. A study on the durability of structural concrete incorporating electric steelmaking slags. Constr. Build. Mater. 2018, 161, 94-111. [CrossRef]

22. Sekaran, A.; Palaniswamy, M.; Balaraju, S. A Study on Suitability of EAF Oxidizing Slag in Concrete: An Eco-Friendly and Sustainable Replacement for Natural Coarse Aggregate. Sci. World J. 2015, 2015. [CrossRef]

23. Tarawneh, S.A.; Gharaibeh, E.S.; Saraireh, F.M. Effect of using steel slag aggregate on mechanical properties of concrete. Am. J. Appl. Sci. 2014, 11, 700-706. [CrossRef]

24. Awoyera, P.O.; Olofinnade, O.M.; Busari, A.A.; Akinwumi, I.I.; Oyefesobi, M.; Ikemefuna, M. Performance of steel slag aggregate concrete with varied water- cement ratio. J. Teknol. 2016, 78, 125-131. [CrossRef]

25. Jiang, Y.; Ling, T.C.; Shi, C.; Pan, S.Y. Characteristics of steel slags and their use in cement and concrete-A review. Resour. Conserv. Recycl. 2018, 136, 187-197. [CrossRef]

26. Monosi, S.; Ruello, M.L.; Sani, D. Electric arc furnace slag as natural aggregate replacement in concrete production. Cem. Concr. Compos. 2016, 66, 66-72. [CrossRef]

27. Pellegrino, C.; Gaddo, V. Mechanical and durability characteristics of concrete containing EAF slag as aggregate. Cem. Concr. Compos. 2009, 31, 663-671. [CrossRef]

28. Wang, Q.; Yan, P.; Yang, J.; Zhang, B. Influence of steel slag on mechanical properties and durability of concrete. Constr. Build. Mater. 2013, 47, 1414-1420. [CrossRef]

29. San-José, J.T.; Vegas, I.; Arribas, I.; Marcos, I. The performance of steel-making slag concretes in the hardened state. Mater. Des. 2014, 60, 612-619. [CrossRef]

30. EN 12457-2. Leaching: Compliance Test for Leaching of Granular Waste Materials and Sludges e Part 2: One Stage Batch Test at a Liquid to Solid Ratio of $10 \mathrm{~L} / \mathrm{kg}$ for Materials with Particle Size below $4 \mathrm{~mm}$; Comité Européen de Normalisation: Brussels, Belgium, 2004.

31. Ministerial Decree. Regolamento Recante Modifiche al Decreto Ministeriale 5 Febbraio 1998 "Individuazione dei Rifiuti non Pericolosi Sottoposti alle Procedure Semplificate di Recupero, ai Sensi Degli Articoli 31 e 33 del Decreto Legislati; 186/2006 Ministerial Decree 04/05/2006 n.186; Ministry for Environment, Land and Sea Protection: Rome, Italy, 2006.

32. EN 12350-2. Testing of Fresh Concrete e Slump Test; Comité Européen de Normalisation: Brussels, Belgium, 2009.

33. EN 12390-3. Testing Hardened Concrete e Compressive Strength of Test Specimens; Comité Européen de Normalisation: Brussels, Belgium, 2011.

34. EN 12390-6. Testing Hardened Concrete—Indirect Tensile Strength of Test Specimens; Comité Européen de Normalisation: Brussels, Belgium, 2010.

35. American Society for Testing and Materials. ASTM C157/C157M-08. Standard Test Method for Length Change of Hardened Hydraulic-Cement Mortar and Concrete; American Society for Testing and Materials: West Conshohocken, PA, USA, 2008.

36. EN 12390-13. Testing Hardened Concrete e Determination of Secant Modulus of Elasticity in Compression; Comité Européen de Normalisation: Brussels, Belgium, 2014.

37. EN 206. Concrete: Specification, Performance, Production and Conformity; Comité Européen de Normalisation: Brussels, Belgium, 2016.

38. Pellegrino, C.; Cavagnis, P.; Faleschini, F.; Brunelli, K. Properties of concretes with black/oxidizing electric arc furnace slag aggregate. Cem. Concr. Compos. 2013, 37, 232-240. [CrossRef]

39. Van Gijlswijk, R.N.; Pascale, S.; De Vos, S.E.; Urbano, G. Carbon footprint of concrete based on secondary materials. Heron. J. 2015, 60, 113-139.

40. EN 1992-1-1. Eurocode 2-Design of Concrete Structures-Part 1-1: General Rules and Rules for Buildings; Comité Européen de Normalisation: Brussels, Belgium, 2004.

41. Ministerial Decree 17/01/2018. Technical Standards of Construction "NTC 2018"; Gazzetta Ufficiale: Rome, Italy, 2018.

42. Flower, D.J.M.; Sanjayan, J.G. Green house gas emissions due to concrete manufacture. Int. J. Life Cycle Assess. 2007, 12, 282-288. [CrossRef]

43. De Brito, J.; Agrela, F. New Trends in Eco-Efficient and Recycled Concrete; Elsevier: Amsterdam, The Netherlands, 2018; ISBN 9780081024805. 